Original Research Article

\title{
Evaluation of efficacy of Carica papaya leaf extracts to increase platelet count in hydroxyurea induced thrombocytopenia in Albino rats
}

\author{
M. Santosh Kumar, Geetha M.*, Mansi J. Shah, Malvika Goyal, Srinivas L. D.
}

Department of Pharmacology, JJMMC, Davangere, Karnataka, India

Received: 16 November 2017

Accepted: 09 December 2017

*Correspondence to:

Dr. Geetha M.,

Email: drgeethamjjmmc

@gmail.com

Copyright: (C) the author(s), publisher and licensee Medip Academy. This is an openaccess article distributed under the terms of the Creative Commons Attribution NonCommercial License, which permits unrestricted noncommercial use, distribution, and reproduction in any medium, provided the original work is properly cited.

\begin{abstract}
Background: Dengue is an infectious disease associated with high mortality and morbidity. Being a viral disease, there is no specific drug available for treatment. There are some reports that Carica papaya leaf extract may improve the clinical condition of dengue patients. However, to support this, at present, there is no systematically searched and synthesized evidence available. Hence this study was undertaken to compare the efficacy of commercial preparation of Carica papaya leaves with freshly prepared Carica papaya leaf extracted.

Methods: 48 albino rats were randomly divided into eight groups of six each. Thrombocytopenia was induced by giving hydroxyurea $(15 \mathrm{mg} / \mathrm{kg})$ orally. Group I and II served as saline and toxic control group respectively. Other six groups were given two different doses of either commercial extract or fresh extract orally for five days. $1 \mathrm{ml}$ of blood was withdrawn at baseline, $3^{\text {rd }}$ and $6^{\text {th }}$ day of the study. Platelet, WBC, RBC count, clotting and bleeding time were determined.

Results: Mean platelet count increased significantly on day 6 in both low dose (2.06 to $\left.4.931 \mathrm{akh} / \mathrm{mm}^{3}\right)$ and human equivalent dose $\left(2.73\right.$ to $\left.7.661 \mathrm{akh} / \mathrm{mm}^{3}\right)$ of commercial extract groups compared to the toxic control group $(\mathrm{p}<0.05)$. Similarly, the mean platelet count increased significantly for human equivalent dose in fresh leaf extract group (3.17 to $4.691 \mathrm{lakh} / \mathrm{mm}^{3}$ ) but the increase in low dose fresh extract $\left(3.28\right.$ to $\left.3.76 l \mathrm{akh} / \mathrm{mm}^{3}\right)$ was not significant. There was no significant rise in mean platelets count, mean RBC count, WBC count, decrease in mean bleeding and clotting time between commercial extract and fresh leaf extract group for both low dose and human equivalent dose.

Conclusions: Efficacy of fresh leaf extract of Carica papaya was not inferior to commercial available preparation. Fresh Carica papaya leaf extract no doubt offers a potential therapeutic efficacy which is cost effective, more affordable and accessible treatment in patients with thrombocytopenia.
\end{abstract}

Keywords: Carica papaya, Platelets, Thrombocytopenia and Hydroxyurea

\section{INTRODUCTION}

Thrombocytopenia is a blood disorder that affects the platelets of the blood. Characteristic features include low platelet count (100000 cells per mm of blood or less) and low platelet survival time. Symptoms include a tendency to bleed excessively into mucous membranes, especially during menstruation. ${ }^{1}$ The most common reasons for thrombocytopenia are; defective production of platelets by the bone marrow, diminished platelet survival and sequestration of the platelets by the spleen. Impaired platelet production occurs in BM failure, megaloblastic anemia, leukaemia, myeloma, myelofibrosis, solid tumor infiltration, aplastic anemia and paroxysmal nocturnal haemoglobinuria $(\mathrm{PNH}){ }^{2}$ Excessive destruction occurs in autoimmune idiopathic thrombocytopenic purpura, SLE, viral infections like EBV, dengue, leptospirosis, chikungunya, and HIV, drug induced thrombocytopenic purpura (for example heparin induced thrombocytopenia), hemolytic uremic syndrome and hypersplenism. ${ }^{3}$ 
The physiological range for thrombocytes in the normal healthy human is $150-400 \times 10^{9} / \mathrm{L}$ of blood. Thrombocytopenia causes few signs and symptoms with platelet counts in the range of $100-150 \times 10^{9} / \mathrm{L}$ that represent mild thrombocytopenia. Platelet counts of 50$100 \times 10^{9} / \mathrm{L}$ and levels less than $50 \times 10^{9} / \mathrm{L}$ are categorized as moderate and severe thrombocytopenia, respectively. In rare cases, the number of platelets may be very low leading to dangerous internal bleeding.

Treatment of thrombocytopenia depends upon the cause. Platelet count often improves when underlying cause is treated or causative medication is stopped. Platelet transfusions are indicated in cases of thrombocytopenia due to decreased platelet production or if active bleeding is present. Of the available methods for treating thrombocytopenia, the treatment method mainly depends on the disease severity. Blood transfusions, steroid treatment, splenectomy, immunosuppressive therapy and intravenous gamma-globulin therapy can be used to correct thrombocytopenia. ${ }^{4-6}$ Moderate and severe thrombocytopenia is associated with morbidity and mortality, the management of which is by drugs and blood products, both of which are costly. Nevertheless, due to certain side effects and the costs involved, the availability of treatment for thrombocytopenia is limited.

The use of a number of medicinal plants and dietary supplements derived from plants as remedies to some human and animal disease conditions have been very popular for a long time now, as these are available at low cost and lack the side effects of drugs. Carica papaya leaves have been successfully employed in folk medicine for the treatment of dengue infections with haemorrhagic manifestations, using suspensions of powdered leaves in palm oil. Carica papaya leaves are being used in Chinese, African, Indian, and Indonesian traditional medicines to increase platelet counts. Recently number of commercial preparations of the Carica papaya leaves extract have flooded the market either as single ingredient or in combination with other ingredients that enhances platelet counts. Papaya plants are available throughout the year in our country with no cost to the patients. The objective of present study is to compare the efficacy of one such commercial preparation of Carica papaya leaves with fresh leaf extract in hydroxyurea induced thrombocytopenia in albino rats. Though there are number of studies published with fresh extract, this is the first study comparing a fresh extract with an available commercial preparation in the market.

\section{METHODS}

\section{Preparation of plant material}

Mature leaves of Carica papaya were collected from a single geographical location, in Davangere. They were washed, blotted dry and after removal of petiole and veins leaf, blades were crushed using a mortar and pestle for 1015 minutes without addition of water. The leaves were pounded and squeezed through muslin cloth to obtain the juice. ${ }^{7}$ To standardize the preparation no water was added and about $10 \mathrm{ml}$ of juice was obtained. The suspension was separated manually from the crushed leaf debris. Fresh extracts were prepared daily for each use. In addition, commercially available Carica papaya was used in the study. Carica papaya leaf extract tablets were obtained from market, manufactured by Micro Labs limited, Bangalore under the brand name Caripill, each tablet contains $1100 \mathrm{mg}$ of extract of Carica papaya leaf. These tablets were dissolved in distilled water just before the administration.

\section{Animals}

Albino rats (100-125g) of either sex were used for the study and they were obtained from the animal house of the department of Pharmacology, JJM Medical College. They were housed in plastic cages under standard conditions of temperature and light, with a $12 \mathrm{hrs}$ light/dark cycle and were fed with pellet food (Krinavally Agrotech ltd, Bangalore) and clear clean drinking water ad libitum.

\section{Induction of thrombocytopenia in rats}

Induction of thrombocytopenia was performed by the oral administration of freshly prepared Hydroxyurea (Cytodrx, Cipla Ltd., India) dissolved in distilled water. Hydroxyurea, anticancer drug is highly toxic drug as it causes myelosuppression. Each rat received $1 / 10^{\text {th }}$ of the standard dose of $15 \mathrm{mg} / \mathrm{kg}$ Hydroxyurea and thrombocytopenia was observed after 24 hours. ${ }^{8}$

\section{Experimental design}

An adult human individual under thrombocytopenic conditions is usually given one tablet of caripill $(1100 \mathrm{mg})$ thrice a day for five consecutive days. ${ }^{9}$ Taking in to consideration the metabolic rate of rats, the human equivalent dose (HE) was approximately equal to the usually used daily dose $(3300 \mathrm{mg})$ by adult patients with thrombocytopenia. ${ }^{10}$ The low dose (LD) was calculated by halving the human equivalent dose $(1650 \mathrm{mg})$.

The drug and fresh leaf extract were administered orally with the help of feeding tube. All the groups were subjected to Hematological analysis (platelet, RBC, WBC, bleeding time and clotting time) at baseline and various time points post treatment.

\section{Blood sample collection}

$1 \mathrm{ml}$ of blood was withdrawn from medial retro-orbital venous sinus of alternate eye on the $1^{\text {st }}$ (baseline before administration of test and control) $3^{\text {rd }}$ and $6^{\text {th }}$ day of the study. Blood platelet, WBC and RBC count was determined manually using neubeures chamber. CT was calculated by capillary method and BT was done manually. 
Table 1: The rats were divided into eight groups of six animals each as mentioned below.

\begin{tabular}{|c|c|c|}
\hline Group & $\mathbf{n}$ & Administration \\
\hline I (Saline control group) & 6 & Saline $10 \mathrm{ml} / \mathrm{kg}$, orally for 5 days \\
\hline $\begin{array}{l}\text { II (Thrombocytopenia group/toxic control } \\
\text { group) }\end{array}$ & 6 & Hydroxyurea on day 1 \\
\hline $\begin{array}{l}\text { III (low dose commercial tab group without } \\
\text { thrombocytopenia) }\end{array}$ & 6 & $\begin{array}{l}\text { Commercially available } 1650 \mathrm{mg} \text { of Carica papaya leaf extract } \\
\text { for five days }\end{array}$ \\
\hline $\begin{array}{l}\text { IV (Low dose commercial tab group with } \\
\text { thrombocytopenia) }\end{array}$ & 6 & $\begin{array}{l}\text { commercially available } 1650 \mathrm{mg} \text { of Carica papaya leaf extract } \\
\text { for } 5 \text { days plus hydroxyurea on day } 1\end{array}$ \\
\hline $\begin{array}{l}\text { V (HED dose commercial tab group with } \\
\text { thrombocytopenia) }\end{array}$ & 6 & $\begin{array}{l}\text { commercially available } 3300 \mathrm{mg} \text { of Carica papaya leaf extract } \\
\text { for } 5 \text { days plus hydroxyurea on day } 1\end{array}$ \\
\hline $\begin{array}{l}\text { VI (Low dose fresh extract group with } \\
\text { thrombocytopenia) }\end{array}$ & 6 & $\begin{array}{l}\text { Fresh Carica papaya leaf extract } 0.18 \mathrm{ml} / 100 \mathrm{gm} / \mathrm{day} \text { for } 5 \text { days } \\
\text { plus hydroxyurea on day } 1\end{array}$ \\
\hline $\begin{array}{l}\text { VII (low dose fresh extract group without } \\
\text { thrombocytopenia) }\end{array}$ & 6 & Fresh Carica papaya leaf extract $0.18 \mathrm{ml} / 100 \mathrm{gm} / \mathrm{day}$ for 5 days \\
\hline $\begin{array}{l}\text { VIII (HED fresh extract group with } \\
\text { thrombocytopenia) }\end{array}$ & 6 & $\begin{array}{l}\text { Fresh Carica papaya leaf extract } 0.36 \mathrm{ml} / 100 \mathrm{gm} / \mathrm{day} \text { for } 5 \text { days } \\
\text { plus hydroxyurea on day one }\end{array}$ \\
\hline
\end{tabular}

\section{Statistical analysis}

All the data was evaluated statistically with SPSS software version 2.0. Platelet, $\mathrm{RBC}$ and $\mathrm{WBC}$ are represented as mean $\pm \mathrm{SD}$ and compared with paired t-test among groups. For post hoc inter group comparison Tukey's test was performed. Differences were considered as significant at $\mathrm{p} \leq 0.05$.

\section{RESULTS}

\section{Commercial extract groups (group IV and V)}

The mean platelet count increased from 2.06 to 4.93 lakh/mm $\mathrm{mm}^{3}$ on day 6 in group IV (low dose commercial extract group) whereas in group V (human equivalent commercial extract group) the rise was from 2.73 to 7.66 $\mathrm{lakh} / \mathrm{mm}^{3}$. The mean platelet count of the above two doses of commercial extract groups showed significant increase when compared to toxic control (group 2) for both day 3 and day 6.

The mean RBC counts, WBC counts showed a significant increase in the commercial extract groups for both low dose (group IV) and human equivalent dose (group V) compared to toxic control group (group $2, \mathrm{P}<0.05$ ) on day 3 and day 6. Their mean bleeding time showed a significant decrease in the commercial extract groups for both low dose and human equivalent dose compared to toxic control group $(\mathrm{P}<0.05)$ on day 3 and day 6 .

Table 2: Mean Platelet (Lakhs/mm3) within the group comparison paired t-test.

\begin{tabular}{|lllllll|}
\hline Groups & Basal & Day -3 & Day-6 & Basal Vs Day 3 & Basal Vs Day 6 & Day 3 Vs Day 6 \\
\hline I & $3.2 \pm 1.6$ & $3.1 \pm 1.48$ & $3.3 \pm 1.64$ & $\mathrm{t}=0.866, \mathrm{P}<0.426$ & $\mathrm{t}=-0.477, \mathrm{P}<0.654$ & $\mathrm{t}=-1.69, \mathrm{P}<0.152$ \\
\hline II & $3.46 \pm 0.60$ & $1.86 \pm 0.41$ & $1.48 \pm 0.29$ & $\mathrm{t}=12.9, \mathrm{P}<0.000$ & $\mathrm{t}=14.53, \mathrm{P}<0.000$ & $\mathrm{t}=4.29, \mathrm{P}<0.008$ \\
\hline III & $2.68 \pm 0.90$ & $4.16 \pm 1.36$ & $5.62 \pm 1.64$ & $\mathrm{t}=-7.58, \mathrm{P}<0.000$ & $\mathrm{t}=-9.57, \mathrm{P}<0.000$ & $\mathrm{t}=-12.0, \mathrm{P}<0.000$ \\
\hline IV & $2.06 \pm 0.45$ & $2.3 \pm 0.46$ & $4.93 \pm 0.29$ & $\mathrm{t}=-7.0, \mathrm{P}<0.001$ & $\mathrm{t}=-15.9, \mathrm{P}<0.000$ & $\mathrm{t}=-13.0, \mathrm{P}<0.000$ \\
\hline V & $2.73 \pm 0.90$ & $4.96 \pm 2.0$ & $7.66 \pm 2.61$ & $\mathrm{t}=-4.79, \mathrm{P}<0.005$ & $\mathrm{t}=-7.07, \mathrm{P}<0.001$ & $\mathrm{t}=-9.24, \mathrm{P}<0.000$ \\
\hline VI & $3.28 \pm 1.4$ & $3.36 \pm 1.39$ & $3.76 \pm 1.36$ & $\mathrm{t}=-0.811, \mathrm{P}<0.454$ & $\mathrm{t}=-1.58, \mathrm{P}<0.175$ & $\mathrm{t}=-1.22, \mathrm{P}<0.276$ \\
\hline VII & $3.39 \pm 1.34$ & $3.59 \pm 1.3$ & $4.2 \pm 1.54$ & $\mathrm{t}=-6.39, \mathrm{P}<0.001$ & $\mathrm{t}=-6.72, \mathrm{P}<0.001$ & $\mathrm{t}=-5.22, \mathrm{P}<0.003$ \\
\hline VIII & $3.17 \pm 1.09$ & $3.16 \pm 1.74$ & $4.69 \pm 3.13$ & $\mathrm{t}=-0.62, \mathrm{P}<0.562$ & $\mathrm{t}=2.71, \mathrm{P}<0.04$ & $\mathrm{t}=-3.12, \mathrm{P}<0.02$ \\
\hline
\end{tabular}

Table 3: Mean platelet (Lakhs/mm3) between the commercial extract groups comparison- Tukey's comparison.

\begin{tabular}{|c|c|c|c|c|c|c|}
\hline Groups & Baseline & Day 3 & Day 6 & Baseline & Day 3 & Day 6 \\
\hline IV & $2.06 \pm 0.45$ & $2.3 \pm 0.46$ & $4.93 \pm 0.29$ & \multirow{2}{*}{$\mathrm{P}<0.000$} & \multirow{2}{*}{$\mathrm{P}<0.000$} & \multirow{2}{*}{$\mathrm{P}<0.000$} \\
\hline II & $3.46 \pm 0.60$ & $1.86 \pm 0.41$ & $1.48 \pm 0.29$ & & & \\
\hline V & $2.73 \pm 0.90$ & $4.96 \pm 2.0$ & $7.66 \pm 2.61$ & \multirow{2}{*}{$\mathrm{P}<0.000$} & \multirow{2}{*}{$\mathrm{P}<0.000$} & \multirow{2}{*}{$\mathrm{P}<0.000$} \\
\hline II & $3.46 \pm 0.60$ & $1.86 \pm 0.41$ & $1.48 \pm 0.29$ & & & \\
\hline
\end{tabular}


Table 4: Mean platelet (Lakhs/ $\mathrm{mm}^{3}$ ) between the fresh leaf extract groups comparison- Tukey's comparison.

\begin{tabular}{|llllll|l|l|}
\hline Groups & Baseline & Day 3 & Day 6 & Baseline & Day 3 & Day 6 \\
\hline VI & $3.28 \pm 1.4$ & $3.36 \pm 1.39$ & $3.76 \pm 1.36$ & \multirow{2}{*}{ P $<0.000$} & \multirow{2}{*}{$\mathrm{P}<0.008$} & $\mathrm{P}<0.569$ \\
\hline II & $3.46 \pm 0.60$ & $1.86 \pm 0.41$ & $1.48 \pm 0.29$ & & \multirow{2}{*}{ P $<0.000$} & \multirow{2}{*}{$\mathrm{P}<0.000$} & $\mathrm{P}<0.018$ \\
\hline VIII & $3.17 \pm 1.09$ & $3.16 \pm 1.74$ & $4.69 \pm 3.13$ & & \\
\hline II & $3.46 \pm 0.60$ & $1.86 \pm 0.41$ & $1.48 \pm 0.29$ & &
\end{tabular}

Table 5: Mean platelet count (Lakhs/ $\left.\mathrm{mm}^{3}\right)$ commercial extract group versus fresh leaf extract groups, Tukey's comparison.

\begin{tabular}{|c|c|c|c|c|c|c|}
\hline Groups & Baseline & Day 3 & Day 6 & Baseline & Day 3 & Day 6 \\
\hline IV & $2.06 \pm 0.45$ & $2.3 \pm 0.46$ & $4.93 \pm 0.29$ & \multirow{2}{*}{$\mathrm{P}<0.07, \mathrm{NS}$} & \multirow{2}{*}{$\mathrm{P}<0.106, \mathrm{NS}$} & \multirow{2}{*}{$\mathrm{P}<0.06, \mathrm{NS}$} \\
\hline VI & $3.28 \pm 1.4$ & $3.36 \pm 1.39$ & $3.76 \pm 1.36$ & & & \\
\hline $\mathrm{V}$ & $2.73 \pm 0.90$ & $4.96 \pm 2.0$ & $7.66 \pm 2.61$ & \multirow{2}{*}{$\mathrm{P}<0.281, \mathrm{NS}$} & \multirow{2}{*}{$\mathrm{P}<0.368, \mathrm{NS}$} & \multirow{2}{*}{$\mathrm{P}<0.188, \mathrm{NS}$} \\
\hline VIII & $3.17 \pm 1.09$ & $3.16 \pm 1.74$ & $4.69 \pm 3.13$ & & & \\
\hline
\end{tabular}

Table 6: Mean WBC count $\left(\mathrm{mm}^{3}\right)$ commercial extract group versus fresh leaf extract groups Tukey's comparison.

\begin{tabular}{|c|c|c|c|c|c|c|}
\hline Groups & Baseline & Day 3 & Day 6 & Baseline & Day 3 & Day 6 \\
\hline IV & $6483.3 \pm 278.7$ & $6716.6 \pm 248.3$ & $6983.3 \pm 213.7$ & \multirow{2}{*}{$\mathrm{P}<0.03$} & \multirow{2}{*}{$\mathrm{P}<0.02$} & \multirow{2}{*}{$\mathrm{P}<0.01$} \\
\hline VI & $5516.6 \pm 957.9$ & $5566.6 \pm 999.8$ & $5716.6 \pm 980.6$ & & & \\
\hline V & $9416.6 \pm 212.0$ & $9650 \pm 1902.4$ & $10500 \pm 1917.3$ & \multirow{2}{*}{$\mathrm{P}<0.481 \mathrm{NS}$} & \multirow{2}{*}{$\mathrm{P}<0.41 \mathrm{NS}$} & \multirow{2}{*}{$\mathrm{P}<0.187 \mathrm{NS}$} \\
\hline VIII & $8566.6 \pm 210.8$ & $8673.3 \pm 2073.2$ & $8846.6 \pm 2125$ & & & \\
\hline
\end{tabular}

Table 7: Mean RBC count (million/ $\mathrm{mm}^{3}$ ) Commercial extract group versus fresh leaf extract groups, Tukey's comparison.

\begin{tabular}{|c|c|c|c|c|c|c|}
\hline Groups & Baseline & Day 3 & Day 6 & Baseline & Day 3 & Day 6 \\
\hline IV & $6.72 \pm 0.37$ & $6.86 \pm 0.28$ & $7.33 \pm 0.27$ & \multirow[b]{2}{*}{$\mathrm{P}<0.795 \mathrm{NS}$} & \multirow[b]{2}{*}{$\mathrm{P}<0.785 \mathrm{NS}$} & \multirow[b]{2}{*}{$\mathrm{P}<0.311 \mathrm{NS}$} \\
\hline VI & $6.57 \pm 1.32$ & $7.01 \pm 1.3$ & $7.95 \pm 1.38$ & & & \\
\hline V & $7.95 \pm 1.0$ & $8.47 \pm 1.14$ & $9.47 \pm 1.05$ & \multirow{2}{*}{$\mathrm{P}<0.582 \mathrm{NS}$} & \multirow{2}{*}{$\mathrm{P}<0.395 \mathrm{NS}$} & \multirow{2}{*}{$\mathrm{P}<0.172 \mathrm{NS}$} \\
\hline VIII & $7.6 \pm 1.10$ & $7.86 \pm 1.19$ & $8.45 \pm 1.33$ & & & \\
\hline
\end{tabular}

Table 8: Mean BT (Minutes) commercial extract group versus fresh leaf extract groups Tukey's comparison.

\begin{tabular}{|c|c|c|c|c|c|c|}
\hline Groups & Baseline & Day 3 & Day 6 & Baseline & Day 3 & Day 6 \\
\hline IV & $1.98 \pm 0.11$ & $1.86 \pm 0.10$ & $1.62 \pm 0.15$ & \multirow{2}{*}{$\mathrm{P}<0.114 \mathrm{NS}$} & \multirow{2}{*}{$\mathrm{P}<0.04$} & \multirow{2}{*}{$\mathrm{P}<0.09 \mathrm{NS}$} \\
\hline VI & $1.75 \pm 0.30$ & $1.58 \pm 0.27$ & $1.33 \pm 0.34$ & & & \\
\hline $\mathrm{V}$ & $1.85 \pm 0.21$ & $1.56 \pm 0.39$ & $0.73 \pm 0.38$ & \multirow{2}{*}{$\mathrm{P}<0.03$} & \multirow{2}{*}{$\mathrm{P}<0.396 \mathrm{NS}$} & \multirow{2}{*}{$\mathrm{P}<0.22 \mathrm{NS}$} \\
\hline VIII & $1.5 \pm 0.28$ & $1.38 \pm 0.31$ & $1.06 \pm 0.51$ & & & \\
\hline
\end{tabular}

Table 9: Mean CT (Minutes) commercial extract group versus fresh leaf extract groups Turkey's comparison.

\begin{tabular}{|c|c|c|c|c|c|c|}
\hline Groups & Baseline & Day 3 & Day 6 & Baseline & Day 3 & Day 6 \\
\hline IV & $2.72 \pm 0.41$ & $2.56 \pm 0.36$ & $2.43 \pm 0.35$ & \multirow{2}{*}{$\mathrm{P}<0.854 \mathrm{NS}$} & \multirow{2}{*}{$\mathrm{P}<0.771 \mathrm{NS}$} & \multirow{2}{*}{$P<0.759 \mathrm{NS}$} \\
\hline VI & $2.78 \pm 0.76$ & $2.66 \pm 0.73$ & $2.53 \pm 0.69$ & & & \\
\hline V & $3.18 \pm 0.88$ & $2.82 \pm 0.92$ & $1.98 \pm 0.99$ & \multirow{2}{*}{$\mathrm{P}<0.442 \mathrm{NS}$} & \multirow{2}{*}{$\mathrm{P}<0.846 \mathrm{NS}$} & \multirow{2}{*}{$\mathrm{P}<0.523 \mathrm{NS}$} \\
\hline VIII & $2.8 \pm 0.77$ & $2.72 \pm 0.74$ & $2.31 \pm 0.73$ & & & \\
\hline
\end{tabular}

There was a decrease in mean clotting time, though not significant in the commercial extract groups (both low dose and human equivalent dose) when compared to toxic control group ( $\mathrm{p}>0.05$ ) on day 3 and day 6 (Table 2 and $3)$.

\section{Fresh leaf extract groups (Group VI and VIII)}

The mean platelet count increased from 3.28 to 3.76 lakh/ $\mathrm{mm}^{3}$ on day 6 in group VI (low dose fresh extract group) whereas in group VIII (human equivalent commercial extract group) the rise was from 3.17 to 4.69 $\mathrm{lakh} / \mathrm{mm}^{3}$ (Figure 1). The mean platelet counts, showed a 
significant increase only on day 3 in low dose group but the human equivalent dose group showed a significant increase on both day 3 and day $6(\mathrm{p}<0.05)$.

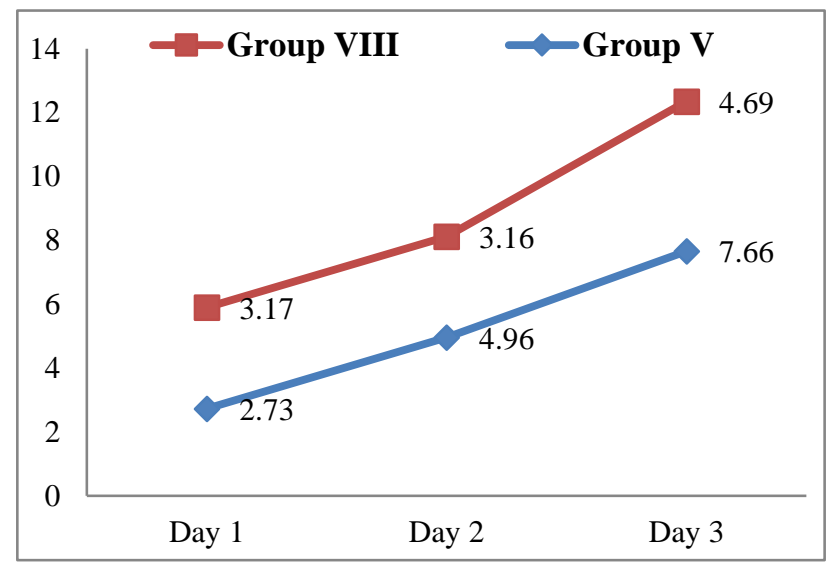

Figure 1: Platelet counts in lakhs $/ \mathrm{mm}^{3}$.

The mean RBC counts, showed a significant increase only on day 6 in low dose group but the human equivalent dose group showed an insignificant increase on both day 3 and day $6(\mathrm{p}<0.05)$

The mean WBC counts, showed an insignificant increase both in low dose group and human equivalent dose group ( $>0.05$ ) on day 3 and day 6 . The mean Bleeding time showed a significant decrease both in low dose group and human equivalent dose group $(\mathrm{p}<0.05)$ on day 3 and day 6 . The mean clotting time showed a decrease though not significant in both low dose group and human equivalent dose group ( $>>0.05$ ) on day 3 and day 6 (Table 2 and 4).

\section{Comparison of commercial extract group (IV and V) versus fresh leaf extract group (Group VI and VIII)}

Though there was a significant increase in mean WBC count and a significant decrease in bleeding time only on day 3 in group IV (low dose commercial extract group) compared to group VI (low dose fresh leaf extract group), there was no significant difference between these two groups in terms of raise in mean platelets count, mean WBC count and mean clotting time on day 3 and day 6 (Table 5 to 9 ).

There was no significant rise in mean platelets count, mean RBC count, WBC count, decrease in mean bleeding time and mean clotting time between group $\mathrm{V}$ (HED of commercial extract group) and group VIII (HED fresh leaf extract group) on day 3 and day 6 (Table 5 to 9 ).

The above results showed rise in platelet, $\mathrm{RBC}$ and WBC count in the commercial extract group which was comparable to the fresh extract group. Similarly, the effect on decrease in bleeding and clotting time was same with no significant difference.

\section{DISCUSSION}

This study was designed to investigate and compare the effect of commercially available tablet with easily available fresh leaf extract of Carica papaya at different doses in hydroxyurea induced thrombocytopenia animal model. Papaya is known as "A powerhouse of nutrients" and was reputably called the "The fruit of Angels" by Christopher Columbus in the $20^{\text {th }}$ century.

Carica papaya leaves contain various phytoconstituents like saponins, tannins, cardiac glycosides and alkaloids (carpaine, pseudocarpaine and dehydrocarpaine I and II). These constituents can act on the bone marrow, prevent its destruction and enhance its ability to produce platelets. Moreover, it can also prevent platelet destruction in the blood and thereby increase the life of the platelet in circulation. ${ }^{11}$ Carica papaya has several therapeutic effects such as antihelmintic, anti-bacterial, antiinflammatory, antioxidant, immunomodulatory effect (increase the production of signalling molecules such as $\mathrm{T}$ helper 1- type cytokines) and as well as in the treatment of dengue fever and its phytochemical components of Carica papaya could be exploited for use in the production of drugs and other medicinal products.

Myelosuppressive drugs (especially hydroxyurea, interferon alfa- $2 b$, antineoplastic drugs) cause diminished or absent megakaryocytes in bone marrow. ${ }^{12}$ After single oral dose of hydroxyurea (antimetabolite), platelet count decreased in group 2 and maximum effect was observed on day 6. Present study showed that the oral administration of freshly prepared leaf extract and commercially available tablets of $C$. papaya, significantly $(\mathrm{p} \leq 0.05)$ increased the platelet counts in both normal and hydroxyurea induced thrombocytopenia in rats. The most potent platelet increasing effect was elicited by the human equivalent dose of both commercial preparation and fresh extract administered orally for 6 consecutively days. Interestingly, the human equivalent dose of both commercial preparation and fresh extract also increased WBC and RBC count significantly $(\mathrm{P} \leq 0.05)$. The human equivalent dose of both preparation decreased both clotting and bleeding time in hydroxyurea induced rats.

A similar published 15 days study conducted with $C$. papaya leaf aqueous extract at concentrations of $400 \mathrm{mg} / \mathrm{kg}$ and $800 \mathrm{mg} / \mathrm{kg}$ in cyclophosphamide-induced thrombocytopenic rat model significantly increased the platelet counts and found also to decrease the clotting time in rats. ${ }^{11}$ Another study using high dose $(0.72 \mathrm{ml} / 100 \mathrm{gm})$ of mature leaf concentrate of $C$. papaya also showed the same effect in hydroxyurea induced thrombocytopenic rat model. ${ }^{13}$ A human study with same commercial tablet preparation, results showed it had significant increase in the platelet count $(\mathrm{p}<0.003)$ over the therapy duration, in dengue fever patients, reiterating that it accelerates the increase in platelet count compared to the control group 9 . The findings of the present study strongly suggest that both the commercial tablet and fresh leaf extract enhance thrombopoiesis and haemopoiesis. There was no much difference between the two compounds in terms of rise in 
platelets, RBC, WBC count and fall in clotting time and bleeding time. We had hypothesized the fresh extract would show better results than the commercial preparation, but the results proved there was no significant difference between both preparations.

\section{CONCLUSION}

From the study it is concluded that both $C$. papaya fresh leaf extract and commercial preparation demonstrated a significant increase in platelet, RBC, WBC count and decrease in BT and CT in both normal as well as in hydroxyurea induced thrombocytopenic rats. Above results indicates that efficacy of fresh leaf extract of Carica papaya was not inferior to commercial available preparation. Fresh Carica papaya leaf extract no doubt offers a potential therapeutic efficacy which is cost effective, more affordable and accessible treatment in patients with thrombocytopenia.

\section{ACKNOWLEDGEMENTS}

Authors would like to thank the Post graduate students and Professors of Department of Pharmacology. Also, would like to extend their thanks to the animal house and Biostatistician of JJMMC, Davangere, India.

Funding: No funding sources Conflict of interest: None declared

Ethical approval: The study was approved by the Institutional Ethics Committee (Ref No. JJMMC/IAEC/052016)

\section{REFERENCES}

1. Shirtcliffe P, Cameron E, Nicholson K, Wiselka M. Don't forget dengue! Clinical features of dengue fever in returning travellers. J R Coll Physicians Lond. 1998;32(3):235-7.

2. Craig JIO, McClelland BDL, Ludlam CA. Blood disease. In: Boon NA, Colledge NR, Walkes BR, eds. Davidson's principles and practice of medicine: $21^{\text {st }}$ Ed. Churchill Livingstone: Elsevier; 2010:985-1051.

3. Sathasivam K, Ramanathan S, Mansor SM, Haris MRMH, Wernsdorfer WH. Thrombocyte counts in mice after the administration of papaya leaf suspension. Wien Klin Wochenschr. 2009; 121:19-22.

4. Patric T, Reddy VB, Grossman EJ, Hammes MS, Trevino HS, Ferrell J, et al. A prospective comparison of three argatroban treatment regimens during hemodialysis in end- stage renal disease. Kidney Int. 2004;66:2446-53.

5. Tefferi A, Michiels JJ, Barui T, Finazzi G, Fuchtman SM, Kutti J, et al. Diagnosis and Treatment of Polycythemia Vera and Possible Future Study Designs of the PVSG. Informa Healthcare. 2000;36:239-53.

6. Bussel JB, Kimberly RP, Inman RD, Schulman I, Cunningham-Rundles C, Cheung N, et al. Intravenous gammaglobulin treatment of chronic idiopathic thrombocytopenic purpura. J Am society Haematol. 1983.

7. Nishant N, Mohanty PK, Dengue SL. Papaya Leaf Is the Cure. Int J Life Sci Res. 2014;2:28-31.

8. Gammulle A, Ratnasooriya WD, Jayakody JRAC, Fernando C, Kanatiwela C, Preethi V. Thrombocytosis and Anti-inflammatory Properties, and Toxicological Evaluation of Carica papaya Mature Leaf Concentrate in a Murine Model. Online Int J Med Plant Res. 2012;1(2):21-30.

9. Gowda AC, Kumar V, Kasture PN, Nagabhushan KH. A pilot study to evaluate the effectiveness of Carica papaya leaf extract in increasing the platelet count in cases of dengue with thrombocytopenia. Ind Med Gazette. 2014:1-7.

10. Dhavan BN, Sirimal RC. Laboratory manual for pharmaceutical evaluation of natural products. International centre for Science and high technology. 2000;7-55.

11. Patil S, Shetty S, Bhide R, Narayanan S. Evaluation of Platelet Augmentation Activity of Carica papaya Leaf Aqueous Extract in Rats. Journal of Pharmacognosy and Phytochemistry. 2013;5:57-60.

12. Guruprasad NB, Dasaraju R. Efffect of Carica papaya leaf extract on hydroxyurea induces hematological and biological parameters in wistar albino rats. 2015;26:15 .

13. Gammulle A, Ratnasooriya WD, Jayakody JRAC, Fernando C, Kanatiwela C, Preethi V. Udagama. Thrombocytosis and Anti-inflammatory Properties, and Toxicological Evaluation of Carica papaya Mature Leaf Concentrate in a Murine Model. 2012;1:21-30.

Cite this article as: Kumar MS, Geetha M, Shah MJ, Goyal M, Srinivas LD. Evaluation of efficacy of Carica papaya leaf extracts to increase platelet count in hydroxyurea induced thrombocytopenia in Albino rats. Int J Basic Clin Pharmacol 2018;7:173-8. 